\title{
THE DEPARTMENT OF HOUSING AND URBAN DEVELOPMENT_BUILDING A NEW FEDERAL DEPARTMENT
}

\author{
DwIGHт A. INk*
}

\section{INTRODUCTION}

When Robert C. Weaver was sworn into office on January I8, I966, as the nation's first Secretary of Housing and Urban Development (HUD), he undertook the most ambitious and dramatic revamping attempted by any Cabinet department in recent years.

The act which created the Department ${ }^{1}$ elevated to Cabinet rank the Housing and Home Finance Agency (HHFA), which he had headed for five years as Administrator, and endowed it with a political fulcrum lacking in the old agency. But this was far more than a pro forma merger of related functions and programs under a newlycreated Cabinet member. The Act characterized in broad terms the role of the Department and the Secretary in relation to other federal agencies and other levels of government; and it vested in the Secretary full powers to integrate and administer the expanded programs and activities of the Department.

At the signing ceremony creating the new Department, President Johnson described it as "a very new and needed instrument to serve all the people of America."

"We are taking the first step," he said, "toward organizing our system for a more rational response to the pressing challenge of urban life."

In the main, organization of the Department was left to the discretion of the Secretary. Only these two major organizational changes were spelled out in the bill:

I. The Act specified that there shall be within the Department a Federal Housing Administration headed by one of the Assistant Secretaries, who would also be the Federal Housing Commissioner. ${ }^{2}$

2. The Act transferred intact to the new department the former agency's mixedownership corporation, the Federal National Mortgage Association, with the Secretary as chairman of its board of directors. ${ }^{3}$

These two provisions signified the beginning of many changes to come in the Department. But these and other revisions during the past year should not obscure the fact that there were also significant changes in the fifteen-year evolution of its predecessor.

At the time HHFA assumed departmental status as HUD it had become one of

- Assistant Secretary for Administration, Department of Housing and Urban Development.

${ }^{1}$ Department of Housing and Urban Development Act, 42 U.S.C. $\$ \$ 3531-37$ (Supp. II, I965-66).

${ }^{2} \$_{4}(\mathrm{a}), 42$ U.S.C. $\$ 3533$ (a) (Supp. II, r965-66).

\$ $\$$ (b), 42 U.S.C. $\$ 3534$ (b) (Supp. II, I965-66). 
the most complex agencies in the executive branch. In fact, the Secretary's Organization Order No. I assigned responsibility within the Department for some fifty-five enumerated programs and activities. And its financial involvement had reached $\$ 73$ billion as of June 30,1965 , the closest date to the establishment of the Department for which the figures were compiled.

This statistic indicates that the HHFA was a very different agency from the one established by Reorganization Plan No. 3 of $1947^{4}$ Under that plan HHFA was strictly a housing agency, consisting of three principal constituents, the Federal Housing Administration, the Home Loan Bank Board, and the Public Housing Administration. Starting with the Great Depression, and spurred by President Roosevelt, a great deal had been done by way of public-assisted housing at the federal level, and it was clear that, so far as the federal government was concerned, public housing was here to stay. The note of urban development, however, was yet the echo of a distant horn.

The first major chord in the new theme was struck in the Housing Act of 1949.5 In title I of that Act Congress recognized that public housing in and by itself was not an effective vehicle for slum clearance-one of its principal stated purposes in 1937. In the 1949 Act the Congress embraced a new concept-not only clearance of slum areas, but their redevelopment in accordance with a plan developed by the community itself. To protect the displaced, the Congress required that a relocation program be developed to make available decent, safe, and sanitary housing. To assure an overall improvement in housing, the Act also required that the area be predominantly residential either before or after its clearance and redevelopment.

Thus, while the focus was still on housing, the Agency was precipitated abruptly into a new and broader dimension-the orderly development and redevelopment of communities in accordance with locally conceived plans and objectives. A number of important steps were taken, both administratively and by congressional action, to channel the Agency's programs in the area of urban planning, including grants for sewers, schools and hospitals, loans and grants for community facilities, grants for open space land, loans and grants to assist mass transportation, and urban beautification.

At the same time the Agency's housing responsibilities were growing and diversifying. They included the college housing loan program, the manufacture of housing, supervision of the Federal National Mortgage Association, loans for prefabricated housing, mortgage insurance programs for housing in urban renewal areas, housing credit for small and remote communities, housing for the elderly and the handicapped.

Thus it is fair to say that when Congress established the new Department in I 965 , the HHFA was already deeply involved in the problems of both housing and urban development.

\footnotetext{
6r Stat. 954 (1947).

${ }^{5} \mathrm{Ch} .33^{8}, 6_{3}$ Stat. $4^{13}$ (codified in scattered sections of 12,42 U.S.C.).
} 


\section{Theory of the New Organization}

It became clear to the new Department that its greatest challenge lay in the area of congestion in the cities, with its growing list of critical urban ills-substandard housing, inadequate schools, overcrowded hospitals, welfare loads, malnutrition, unemployment, pollution of air and water, insufficient recreational facilities, and the tremendous upsurge of crime and delinquency in the streets. What was neededand obviously lacking in the past-was a comprehensive and realistic urban policy, linking together administratively the many urban aid programs and envisaging the city in terms of total urban development, sociological as well as physical.

The knottiest problem in approaching the organization of the new Department was to determine the most effective method in which to group its manifold programs and activities to respond to these urban needs. Of the various available alternatives, the one selected was the grouping of functions and programs in such a manner that the organization format itself would tend to compel problems to be resolved in the context of other, related problems-regardless of historical program distinctions or past organizational separation. The Congress implicitly espoused this approach in the departmental act, when it gave separate organizational recognition to "programs relating to the private mortgage market."

Taking this as the first, a second grouping of functions was put together dealing essentially with the problems of the central city. This included, for instance, urban renewal, public housing, aids to the provision of neighborhood centers and similar facilities, and the provision of open space and beautification in densely built-up central areas. Also placed here was the focal point for dealing with the relocation problems of urban families.

A third such grouping was made up of functions and programs dealing with metropolitan areas and the urbanizing countryside. It included such programs as grants for preservation of open space as urbanization spills outward; assistance for area-wide planning; grants for water and sewer development, geared to the concept of developing area-wide systems; aids for urban mass transportation; and assistance in advance planning for, and acquisition of land for future, public need.

A fourth grouping brought together the Department's demonstration programs such as Model Cities, and the wholly new and developmental work in the area of intergovernmental relations-the search for more effective means of coordination within and among the federal, state, metropolitan and municipal levels of government. $^{7}$

The Department was now organized on a basis which would enable Secretary

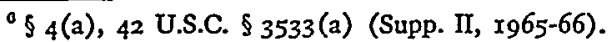

7 New as it is, the organization of the Department is understandably still in a state of growth and change. Pending legislation (H.R. 8068, goth Cong., Ist Sess. (1967) and S. 1445, 9oth Cong., ist Sess. (I967)) requests congressional authorization of an additional Assistant Secretary to handle research, engineering, and urban technology.
} 
Weaver to harness all its resources effectively and efficiently. Five semi-autonomous units were melded into a single cohesive Department, with all authority given by statute to the Secretary.

This organizational approach would be open to the charge of over-simplification if it had been based on the assumption that these were neat, self-contained packages. It was not. It recognized that the problems of the central city are different from those of the urbanizing fringe, and are more closely interrelated with each other than with those of the urbanizing fringe. But it also recognized that none of these problems can be wholly isolated from any other.

Thus, for example, most public housing is located in central cities, but some is not. There is, indeed, no generally acceptable or applicable definition of the term "central city." Incorporated limits grow progressively less meaningful as urban population and attitudes outgrow established political jurisdictions. Urban transportation systems, while they are organic functions of whole regional economic areas, strike into the heart of the central city with profound effects on housing, commerce, land values, and an infinite variety of other municipal concerns. These considerations were fully recognized in the organizational approach.

This organizational thesis had a most interesting consequence in the role established for the Assistant Secretaries within the Department. The current concept in public administration is that a top official should occupy either a line role or a staff role. He either occupies a position in the line of command, receiving authority from his superior and conveying it to his subordinates, or he stands aside from the command chain as one who analyzes problems, accumulates information, and advises or proposes.

When it came to the concrete problem of organizing the Department, however, this conventional solution proved inadequate. What was needed was a senior representative of the Secretary who was concerned both with effective program execution and with the Department-wide interrelationships exemplified earlier.

Again, the Congress itself took the lead when it stipulated that one Assistant Secretary should be at once the Federal Housing Commissioner and the Secretary's principal adviser in connection with programs related to the private mortgage market-thus by law enjoining him to perform a mixed line and staff function. The solution adopted on a Department-wide basis followed this congressional concept. An Assistant Secretary was given overall leadership and command responsibility for each of the four functional areas briefly summarized above; at the same time, the Assistant Secretaries collectively were given the responsibility of serving, in the Secretary's words, as his "general staff for the management of the Department." Sitting in this capacity, they are not expected to be simply advocates or spokesmen for the programs under their direction, but jointly to review, evaluate and contribute to the Department's approach to its entire mission.

The five Assistant Secretaries operate as a closely knit team. Frequently they meet 
together in their homes to review the Department's basic policy objectives in the interest of making the Department function more efficiently.

A Budget Review Committee consisting of the Assistant Secretaries and Deputy Under Secretary meets regularly, with Under Secretary Robert Wood serving as chairman, to compare respective programs and recommend to the Secretary its collective judgment on the allocation of departmental resources.

A Deputy Under Secretary for Policy Analysis and Program Evaluation performs the function of comparing programs, sharpening policy objectives and reviewing the extent to which the Department carries out those objectives.

In addition there was a major consolidation of the administrative functions of the Department. In personnel, accounting, audit, general services and budget, the responsibility for establishing department-wide policies and standards and for carrying out operations on a centralized basis for most of the activities of the Department was consolidated at the departmental level under the Assistant Secretary for Administration.

\section{II}

\section{STRENGTHENING THE FieLD}

Equally important was the approach taken to organization of the Department's facilities in the field. Here again the principle adopted as a guide was the effort to get individual decisions concerted with other related decisions affecting the same community -regardless of program lines. In order to accomplish this, four major changes were made:

I. The regional administrators who head the Department's seven regional offices were made the representatives of and the spokesmen for the Department as a whole in their respective geographic areas.

2. The regional administrators report directly to the Secretary as line managers directly responsible for the programs developing in their jurisdictions.

3. The formerly separate regional offices for the public housing program and for FHA multifamily housing programs were physically and organizationally merged into the regional offices of the Department. Exempted from this change, for obvious practical reasons, was the function of the FHA state and local insuring offices in connection with insurance of mortgages on one to four family homes.

4. A new coordinative function was established directly under the regional administrator to assure common assumptions and common policies on programs which have an impact in a particular community. As the Secretary described the intent of this new arrangement::

Thus, any project originating in any of these programs will be fed through a central review point which will check out and bring to light its relationships to

\footnotetext{
${ }^{8}$ Hearings on the Independent Offices and Department of Housing and Urban Development Appropriations for 1968 before the Subcomm. on Independent Offices and Department of Housing and Urban Development of the House Comm. on Appropriations, goth Cong., Ist Sess., pt. 3, at 7 (I967).
} 
or its significance for other programs being carried out in the same community; its relationship to the workable program of the community; how it stacks up in terms of the latest information available to the Department on market conditions in the area; how it fits in with local planning for the development of the area as a whole; and whether the community has realistically identified and made sound provision for the relocation problems which its proposed project or projects will bring about.

As more strength is added to the regions, the Department is now proceeding to the next step of delegating more responsibility to them-a task not without its difficulties and stumbling blocks. The process of decentralization does not lend itself automatically to all programs. As a general rule, established programs with welldrawn policy and procedures guidelines can be delegated to the field, while authority over new programs often must be reserved to Washington because of their precedentsetting character.

With respect to a given program, however, it is not simply a question of whether all the decision making process rests in Washington or whether it should be delegated to the field. Most programs involve a number of different elements, ranging from the initial application for a planning grant, through the planning phase, and the award and implementation of the program itself.

Within a particular program some of these elements may be decentralized; and, with the passage of time, more of them will generally lend themselves to decentralization. The Model Cities program is one example of a new and precedent-setting undertaking in which project approvals must be made in Washington. But the regional offices are heavily involved in the project review process, and will administer this program together with the field representatives of other departments that are also heavily involved.

These arrangements mean that communities participating in HUD programs can be served more directly and efficiently. A central point of contact has been established in the field for local agencies and officials, cutting the time and distance between the need for action and the decision to act.

\section{III}

\section{INTERDEPARTMENTAL COOpERATION AND INTERgovernmental Relations}

The departmental act specifies that the Secretary shall "exercise leadership at the direction of the President in coordinating Federal activities affecting housing and urban development." $\mathrm{He}$ is also directed to "encourage comprehensive planning by the State aud [sic] local governments with a view to coordinating Federal, State, and local urban and community development activities."10 In brief, HUD was created to help give form and substance to President Johnson's concept of "creative fed-

\footnotetext{
${ }^{8} \S 3$ (b), 42 U.S.C. $\S 3532$ (b) (Supp. II, 1965-66).

${ }^{10}$ Id.
} 
eralism"-a concept in which the resources of all three levels of government are focused on solving major problems.

The importance of this approach was recognized at the Assistant Secretary level, and a premium was placed on acquiring new methods and techniques to achieve greater cooperation among federal agencies and with other government bodies.

In the past, many types of machinery were tried, one of which was the standing interdepartmental committee. This, in my opinion, has been unsatisfactory. Standing committees waste time and delay decisions. After a while most permanent committees tend to deteriorate and become of limited use. The Department is now developing less formal and more flexible links with the other chains of government through informal working groups and task forces which have limited objectives and operate for a prescribed time.

Under the so-called "Convenor Order,"11 the Secretary is authorized to convene meetings of Departments and agencies having responsibilities related to common problems. Thus, the order is a significant document and a meaningful instrument in getting people and institutions to work together with common policies and common goals.

The Model Cities program offers a workable illustration of how the Department is attempting to develop effective ways to draw together the right people at the right time to deal with specific problems or policy issues. Applications for Model Cities planning grants have been filed by almost 200 local communities. These are reviewed in the field on an inter-agency basis by the four principal agencies involved -HUD, Health, Education and Welfare, the Office of Equal Opportunity (OEO), and the Department of Labor-plus the Community Relations Service of the Justice Department and the Economic Development Administration of the Commerce Department.

Reports on the capabilities of the applicant cities are sent by the field to a Review Committee in Washington headed by Assistant Secretary Ralph Taylor of HUD and consisting of representatives from the principal agencies, and the other two agencies if they are involved. The Review Committee in turn recommends the cities to be selected by Secretary Weaver for Model City planning grants. Each agency must administer its own component of the program, but in a manner which would preserve the overall integrity and character of the program.

\section{Considering the Human Factor}

In seeking to mesh social and economic factors with the physical elements of urban development, the human factor has not been neglected. For example, there is today a far greater emphasis on the rehabilitation of existing neighborhoods and individual buildings, as opposed to the former practice of clearing areas with bull-

\footnotetext{
${ }^{11}$ Exec. Order No. Ir,297, 3 C.F.R. I4I (Comp. I966).
} 
dozers to make way for new projects. Special units have been established at headquarters and in each regional office to reduce to a minimum the problem of relocation in cases where people must be moved even temporarily because of federal projects. The Department is also working far more closely in this area with peopleoriented agencies such as the Department of Health, Education and Welfare, the Department of Labor, and the Office of Economic Opportunity.

\section{Research NeEDS}

While progress has been made on many fronts, one of the areas in which we have been lagging is research. It seems a curious thing that there has never been a coordinated, concentrated research program focused on housing and urban problems. Sporadic investigations have been undertaken, of course, by universities and foundations, and the federal government has made some contribution. But these have been isolated and topical efforts-often valuable in themselves, but not constituting a plan or scheme of orderly investigation. As the Secretary testified to the House Committee on Appropriations: ${ }^{12}$

In our view, this is a major area of neglect. Sophisticated research techniques and a close working partnership between the Federal Government and private industry, universities, and private research foundations have yielded spectacular results in agriculture, in public health, in space exploration, and in many other areas. It is sad but true that nothing even remotely comparable exists to investigate and throw light on the problems that plague our cities and the people who live in them.

As this is written, the probability seems good that there will be made available for the first time a substantial appropriation for research in housing and urban technology. This will be a major step toward the realization of the aims for which the Department was established.

Such an appropriation will bring into meaningful focus two responsibilities of the Secretary as set forth in the basic act: first, to conduct studies of problems of housing and urban technology; second, to conduct a clearinghouse service to make such information available to all levels of government-federal, state, metropolitan and local. The format and mechanics of such a service remain to be worked out. But whatever the mechanics, we have the right to feel hopeful that we are entering a period when decisions of public policy in the field of urban affairs can be made on the basis of better information and understanding.

Toward that objective, an Office of Urban Technology was recently established in HUD, and President Johnson has sought congressional authorization to expand the Office under an Assistant Secretary. It is the hope of the Department that many of the methods and techniques developed in the aerospace and defense areas can be adapted for the improvement of the urban environment.

\footnotetext{
${ }^{12}$ Hearings, supra note 8 , at 4 .
} 
New Legislation Accelerates Department's Efforts

As we continued the Department's building program, several new pieces of legislation gave new thrust and direction to HUD's efforts to achieve greater coordination among programs with an urban impact.

One of these was the rent supplement program for low income families, authorized by the Housing and Urban Development Act of $1965 .{ }^{13}$ The act also authorized rehabilitation grants to the owner-occupants of homes in urban renewal areas and federally-assisted code enforcement areas, and a new program of FHA mortgage insurance for the purchase of homes by veterans.

The Demonstration Cities and Metropolitan Development Act of $1966^{14}$ authorized supplemental grants where development in metropolitan areas is being carried out in accordance with metropolitan planning and programming; grants to states to help finance urban information and technical services to small communities; and broadened the mortgage insurance program for land development to provide insured mortgage financing for new communities. The Secretary was also authorized to carry out a comprehensive program of studies of urban environment factors.

\section{VII}

\section{The Departaient Now Fully Organized}

The foregoing steps which have taken place during the past year add up to a precedent-setting reorganization both in headquarters and the field. During this same period the Department also has endeavored to provide a new emphasis on meshing economic, social and physical planning in relation to urban problems. Plans have been developed for a diversified research program, and a whole new approach to federal grants-in-aid administration has been undertaken through the Model Cities program.

The massive shifts of functions and staff required to accomplish these objectives have been completed. We believe the Department is now organized on a basis which better enables it to develop and initiate major new programs, as well as increasing the effectiveness of existing programs.

This does not mean, of course, that the Department has perfected its organization procedures and techniques. HUD is still going through its shakedown period, and many procedures must be adjusted to the new organization. A major effort has been launched to speed up the processing of grants through a Joint Administrative Task Force consisting of representatives from HUD, HEW, OEO, and Labor.

Although we want to further strengthen the Department, I believe HUD has now emerged as a vital reality and a major factor in the contemporary American scene.

\footnotetext{
${ }^{13}$ I2 U.S.C. \$ I70Ts (Supp. II, I965-66).

14 Pub. L. No. 89-754, 80 Stat. 1255 (codified in scattered sections of $\mathrm{II}, \mathrm{I2}, 15,16,40,42$ U.S.C.).
} 